\title{
Macro scale analysis of Syrah vineyards under winter growing cycles: Agronomical and ecophysiological responses
}

\author{
Luciana Alves Caldeira Brant ${ }^{*}{ }^{\star}\left(\mathbb{0}\right.$, Cláudia Rita de Souza ${ }^{2}$, Renata Vieira da Mota ${ }^{\circledR}$, Fernanda de Paula Fernandes ${ }^{3}$, Mariana

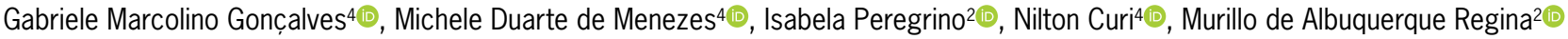

'Universidade Federal de Lavras - Depto. de Agricultura, C.P. 3037 - 37200-000 - Lavras, MG - Brasil.

${ }^{2}$ Centro Tecnológico EPAMIG Uva e Vinho, Av. Santa Cruz, 500 - 37780-000 - Caldas, MG - Brasil.

3Universidade do Vale de São Francisco - Campus Ciência Agrícola, Rod BR 407, C.P. 252 - 56300-000 - Petrolina, PE - Brasil.

${ }^{4}$ Universidade Federal de Lavras - Depto. de Ciência do Solo - Lavras, MG - Brasil.

*Corresponding author <lucianacbrant@yahoo.com.br>

Edited by: Axel Garcia y Garcia

Received March 03, 2020

Accepted June 01, 2020
ABSTRACT: In Southeast Brazil, the change of grape harvest from wet summer to dry winter through double-pruning management has improved the quality of wines, currently denominated winter wines. In order to better understand the influences of soil, macroclimate, and vineyard management in winter wines, we investigated seven vineyards in the states of Minas Gerais (Três Corações - TC, Três Pontas - TP, Cordislândia - COR, São Sebastião do Paraíso - SSP and Andradas - AND) and São Paulo (Itobi - ITO and Espirito Santo do Pinhal - PIN) during three consecutive growing seasons. The vineyards are located in warm temperate zones and grouped in four soil types: Acrudox in TC, AND and SSP, Hapludox in TP; Hapludult in AND and PIN; Eutrudept in ITO. The high clay content (> $35 \%$ ) observed in all soil types, associated to low evapotranspiration demand, avoided the occurrence of severe water stress, as observed by the high values of leaf and stem water potential, stomatal conductance, photosynthesis, and transpiration. Differences in vigor were more related to vineyard management and did not affect grape composition. Among vineyards, parameters for berry quality from ITO, such as sugar and acidity, were more associated to high soil sand content and winter temperature. No significant differences were found in anthocyanins and total phenols of berries among vineyards, suggesting that the high thermal range and low precipitation during autumn-winter, historically observed in all municipalities, seemed to be the main factor for improvement of phenolic compounds.

Keywords: Vitis vinifera, Double-pruning grape composition, vegetative vigor, terroir

\section{Introduction}

Traditionally, in Southeast Brazil, wine grapes are harvested during the summer (Dec - Jan), a period of heavy precipitation, which increases cluster rot incidence and impairs berry ripening. However, studies have shown an improvement of grape quality by changing the harvest period from wet and warm summer to dry and mild autumn - winter through double-pruning management (Favero et al., 2011; Regina et al., 2011; Brant et al., 2018). Under this management, the vines are first spur pruned at the end of winter (Aug - Sept) to develop the vegetative cycle, where all clusters are removed. The productive cycle starts after a second spur pruning, performed in Jan - Feb, to allow grape harvest during the winter period (July - Aug) (Favero et al., 2011).

Studies have reported that the low rainfall and high thermal range of the autumn-winter season are favorable to sugar accumulation and synthesis of phenolic compounds in berries from grapevines grown under warm temperate and tropical conditions in southeastern Brazil (Favero et al., 2011; Mota et al., 2011a,b; Regina et al., 2011). In this region, the wine elaborated with grape harvested during the winter is called "winter wine" and awards in several national and international competitions have recognized its quality.

Recently, viticulture in southeastern Brazil has grown considerably. In this site, approximately 150 ha of vines are cultivated under double-pruning management
(Brant et al., 2018). In these vineyards, the Syrah cultivar has shown the best performance with higher yield (Regina et al., 2011).

Grape composition, mainly phenolic compounds, is highly influenced by terroir. Terroir includes characteristics, such as soil type, climate (sunlight, temperature and rainfall), topography and human actions and their influence on gape quality and, therefore, wine quality and specificities (Ballantyne et al., 2019; Coggins et al., 2019; Van Leeuwen, 2010).

As a first attempt to identify geographical indications for winter wine in Brazil, this study aimed to understand the potential and typicality of wines elaborated with Syrah grapes grown in different terroir zones of the southeastern region of Brazil in the autumn-winter season. Vine development, yield, and berry composition of Syrah vines were characterized in seven vineyards in the states of Minas Gerais (MG) and São Paulo (SP) during three consecutive growing seasons under different soil types, climate, and vineyard management. We expect this research provides a protected geographical indication for winter wines in the near future.

\section{Materials and Methods}

\section{Vineyard description}

The study was carried out during 2016, 2017 and 2018 growing seasons in seven Syrah commercial vineyards located in different municipalities of Southeast 
Brazil: Cordislândia (COR), Andradas (AND), São Sebastião do Paraíso (SSP), Três Pontas (TP), and Três Corações (TC) in Minas Gerais; and Espírito Santo do Pinhal (PIN) and Itobí (ITO) in São Paulo. The selected vineyards were between 10 and 15 years old. In general, the experimental sites are located at an average of 900 meters above sea level, the average temperature is $20^{\circ} \mathrm{C}$ $( \pm 0.5)$ and the average total annual precipitation is 1462 $\mathrm{mm}( \pm 82)$. All sites are located near the coffee region of MG and SP (Figure 1).

All Syrah grapevines used in this study were grafted onto rootstock 1103 Paulsen (Vitis berlandieri $\times$ Vitis rupestris), trained in vertical shoot position with bilateral cordons spaced $2.5 \mathrm{~m} \times 1.0 \mathrm{~m}(4000$ plants $\mathrm{ha}^{-1}$ ) and pruned in two-node spurs, for both pruning, totaling 20 latent buds per plant, on average.

Double-pruning management was applied according to Favero et al. (2011). The first pruning was done in Aug (vegetative cycle) for latent bud formation and the second was done in Jan in lignified shoots (reproductive cycle) for grape production. In both cycles, the buds were sprayed after pruning with hydrogen cyanamide at $5 \%$ to stimulate and standardize the budburst. During the vegetative cycle, all clusters were removed when the berries were at green pea stage.

All cultural practices were performed according to viticulturists of the farms. The 2016 data from the TC vineyard was not included in the study because fruitfulness of latent bud developed in previous season (Aug to Sept of 2015) was drastically reduced by high downy mildew attack.
Climate data were obtained from Climate.Data. org (https://pt.climate-data.org/), an online platform that makes available worldwide historical weather data. Results are expressed as means of a period of 30 years, from 1982 to 2012 (Table 1).

Soil profile samples were collected in the central part of each experimental area plot and described according to Santos et al. (2015) and characterized according to Soil Survey Staff (2014) (Table 2). Sand, silt, and clay contents were determined according to Gee and Bauder (1986).

\section{Vegetative vigor and ecophysiological evaluations}

During the ripening period, vegetative vigor (leaf area and pruning weight), photosynthesis, transpiration, stomatal conductance and vine water status were evaluated to characterize the ecophysiological performance of vines in all vineyards, using 10 replicates per site (one vine per replicate). The leaf area per vine was estimated through nondestructive method. Single leaf area was estimated using the equation $\mathrm{y}=41.5501-$ $5.0167 x+0.5269 x^{2} ;$ where $y$ is the estimated single leaf area and $x$ is the sum of lengths of two main lateral leaf veins (Regina et al., 2000). The average single leaf area was obtained from eight to 10 leaves per shoot and the average shoot leaf area from four shoots per vine. The total leaf area per vine was calculated by multiplying the average shoot leaf area by the total number of shoots per vine. The pruning weight of vines was measured one month after grape harvest in the same vines sampled for leaf area estimation. All shoots per vine were pruned

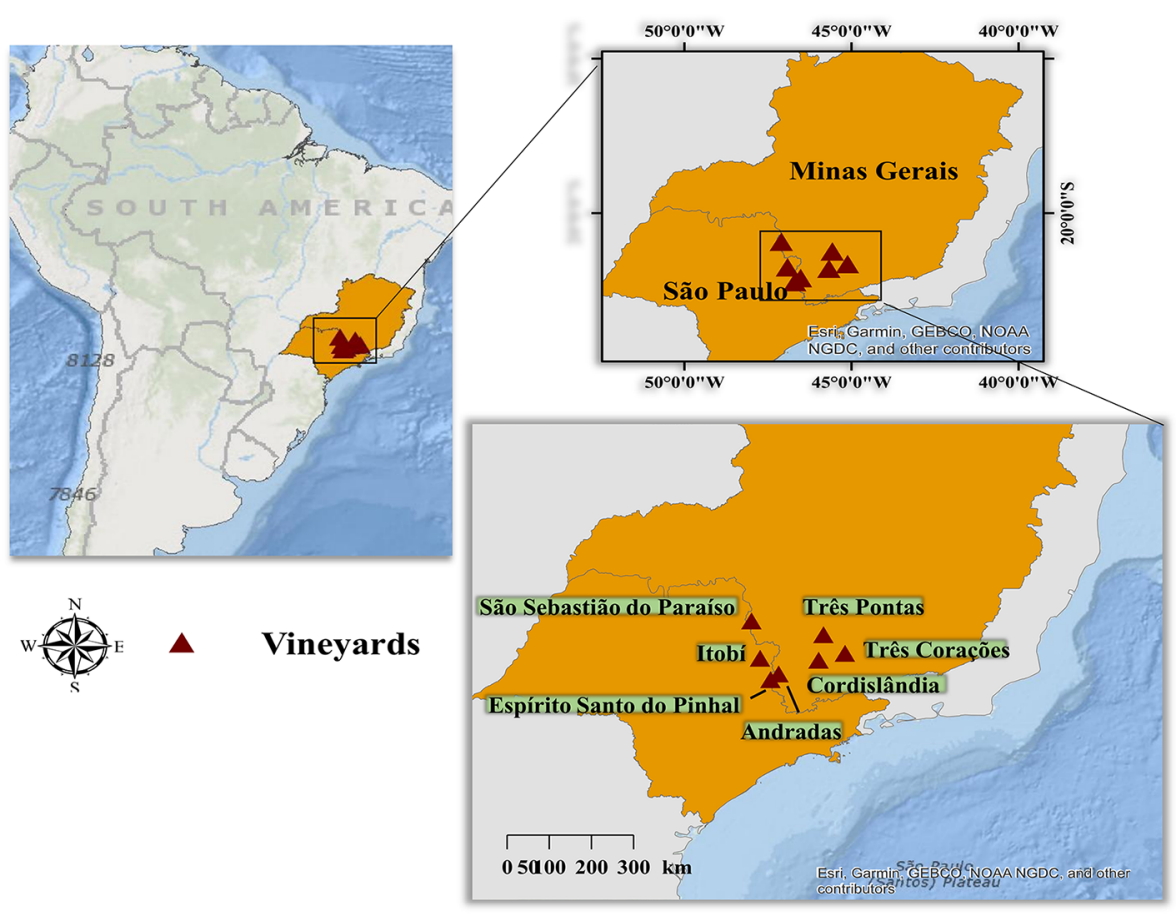

Figure 1 - Geographic location of the vineyards in Minas Gerais and São Paulo States. 
Table 1 - Geographic location and historical climatic data of municipalities in Southeast Brazil producing Syrah grapes under double-pruning management.

\begin{tabular}{|c|c|c|c|c|c|c|c|c|c|c|c|c|c|c|c|}
\hline \multirow{2}{*}{ Region } & \multirow{2}{*}{$\begin{array}{l}\text { Köppen Climate } \\
\text { Classification }\end{array}$} & \multirow{2}{*}{ Climatic Variable } & \multicolumn{12}{|c|}{ Months } & \multirow{2}{*}{ Year } \\
\hline & & & Jan & Feb & Mar & Apr & May & Jun & July & Aug & Sept & Oct & Nov & Dec & \\
\hline \multirow{5}{*}{$\begin{array}{l}\text { Três Corações } \\
\text { Latitude } 21^{\circ} 36^{\prime} \mathrm{S} \\
\text { Longitude } 45^{\circ} 7^{\prime} \mathrm{W} \\
\text { Altitude } 865 \mathrm{~m}\end{array}$} & \multirow{5}{*}{ Cwa } & Mean temperature $\left({ }^{\circ} \mathrm{C}\right)$ & 23 & 23.2 & 22.2 & 20.2 & 17.9 & 16.2 & 16.4 & 18.2 & 19.9 & 21.1 & 21.8 & 22.1 & $20.2 \pm 2.5$ \\
\hline & & Minimum temperature $\left({ }^{\circ} \mathrm{C}\right)$ & 17.2 & 17.3 & 16.3 & 13.8 & 10.7 & 8.3 & 8.4 & 9.9 & 12.5 & 14.7 & 15.8 & 16.4 & \\
\hline & & Maximum temperature $\left({ }^{\circ} \mathrm{C}\right)$ & 28.9 & 29.1 & 28.1 & 26.7 & 25.1 & 24.1 & 24.4 & 26.6 & 27.4 & 27.6 & 27.8 & 27.8 & $27.0 \pm 1.7$ \\
\hline & & Thermal amplitude $\left({ }^{\circ} \mathrm{C}\right)$ & 11.7 & 11.8 & 11.8 & 12.9 & 14.4 & 15.8 & 16 & 16.7 & 14.9 & 12.9 & 12 & 11.4 & $13.5 \pm 1.9$ \\
\hline & & Preci & 246 & 205 & 168 & 58 & 37 & 20 & 15 & 20 & 65 & 123 & 174 & 270 & \\
\hline \multirow{5}{*}{$\begin{array}{l}\text { Três Pontas } \\
\text { Latitude } 21^{\circ} 12^{\prime} \mathrm{S} \\
\text { Longitude } 45^{\circ} 35^{\prime} \mathrm{W} \\
\text { Altitude } 881 \mathrm{~m}\end{array}$} & \multirow{5}{*}{ Cwa } & Mean te & & 22.7 & 21.7 & 19.9 & 17.4 & 16.3 & 16.6 & 18.3 & 19.9 & 21.1 & 21.7 & & \\
\hline & & Minimur & 17.2 & 17 & 15.8 & 13.5 & 10.3 & 8.7 & 8.6 & 10.3 & 12.8 & 14.8 & 15.8 & 15.9 & \\
\hline & & Maximu & 28.6 & 28.4 & 27.7 & 26.3 & 24.6 & 23.9 & 24.6 & 26.3 & 27.1 & 27.5 & 27.6 & 27.5 & \pm 1.6 \\
\hline & & & 11.4 & 11.4 & 11.9 & 12.8 & 14.3 & 15.2 & 16 & 16 & 14.3 & 12.7 & 11.8 & 11.6 & \\
\hline & & & & 212 & 165 & 65 & 42 & 27 & 22 & 24 & 66 & 128 & 175 & 265 & \\
\hline \multirow{5}{*}{$\begin{array}{l}\text { Cordislândia } \\
\text { Latitude } 21^{\circ} 40^{\prime} \mathrm{S} \\
\text { Longitude } 45^{\circ} 55^{\prime} \mathrm{W} \\
\text { Altitude } 873 \mathrm{~m}\end{array}$} & \multirow{5}{*}{ Cwa } & & 23.2 & 23 & 21.7 & 20.1 & 17.5 & 16.5 & 17.1 & 19 & 20.4 & 21.7 & 22.1 & 21.7 & \\
\hline & & Minir & 17.4 & 17.2 & 15.6 & 13.9 & 10.3 & 8.8 & 9.2 & 11.1 & 13.4 & 15.4 & 16.4 & 15.9 & \\
\hline & & Maxir & 29 & 28.9 & 27.9 & 26.4 & 24.8 & 24.3 & 25 & 26.9 & 27.5 & 28 & 27.9 & 27.5 & \\
\hline & & & 11.6 & 11.7 & 12.3 & 12.5 & 14.5 & 15.5 & 15.8 & 15.8 & 14.1 & 12.6 & 11.5 & 11.6 & \\
\hline & & & & 94 & 157 & 67 & 43 & 27 & 23 & 26 & 63 & 129 & 172 & 261 & \\
\hline \multirow{5}{*}{$\begin{array}{l}\text { Andradas } \\
\text { Latitude } 22^{\circ} 3^{\prime} \mathrm{S} \\
\text { Longitude } 46^{\circ} 32^{\prime} \mathrm{W} \\
\text { Altitude } 1000 \mathrm{~m}\end{array}$} & \multirow{5}{*}{ Cwa } & & 22.3 & 22.7 & 22.2 & 20.2 & 18.4 & 16.4 & 16 & 17.9 & 19.7 & 20.8 & 21.7 & 21.9 & \\
\hline & & Minim & 17.1 & 17.2 & 16.6 & 14 & 12.2 & 9.2 & 8.6 & 10.2 & 12.8 & 14.8 & 16 & 16.8 & \\
\hline & & Maxin & 27.6 & 28.2 & 27.8 & 26.4 & 24.7 & 23.6 & 23.5 & 25.6 & 26.6 & 26.9 & 27.4 & 27.1 & \\
\hline & & & 10.5 & 11 & 11.2 & 12.4 & 12.5 & 14.4 & 14.9 & 15.4 & 13.8 & 12.1 & 11.4 & 10.3 & 12. \\
\hline & & & 275 & 214 & 188 & 82 & 52 & 37 & 26 & 31 & 73 & 133 & 190 & 278 & \\
\hline \multirow{5}{*}{$\begin{array}{l}\text { Itobí } \\
\text { Latitude } 21^{\circ} 42^{\prime} \mathrm{S} \\
\text { Longitude } 46^{\circ} 55^{\prime} \mathrm{W} \\
\text { Altitude } 840 \mathrm{~m}\end{array}$} & \multirow{5}{*}{ Cwa } & & 22.9 & 23.1 & 22.5 & 20.9 & 18.3 & 17 & 16.9 & 18.6 & 20.5 & 21.6 & 22.2 & 22.6 & \\
\hline & & & 17.8 & 17.8 & 17.1 & 14.9 & 11.8 & 10 & 9.7 & 11.4 & 13.8 & 15.8 & 16.9 & 17.3 & \\
\hline & & Maxin & 28 & 28.4 & 28 & 26.9 & 24.9 & 24.1 & 24.1 & 25.8 & 27.2 & 27.5 & 27.5 & 27.9 & \\
\hline & & & 10.2 & 10.6 & 10.9 & 12 & 13.1 & 14.1 & 14.4 & 14.4 & 13.4 & 11.7 & 10.6 & 10.6 & $12.2 \pm 1.6$ \\
\hline & & & 243 & 202 & 172 & 60 & 36 & 34 & 19 & 20 & 52 & 119 & 167 & 227 & \\
\hline \multirow{5}{*}{$\begin{array}{l}\text { Espírito Santo do } \\
\text { Pinhal } \\
\text { Latitude } 22^{\circ} 10^{\prime} \mathrm{S} \\
\text { Longitude } 46^{\circ} 42^{\prime} \mathrm{W} \\
\text { Altitude } 1270 \mathrm{~m}\end{array}$} & \multirow{5}{*}{ Cwb } & & & 21.9 & 21.6 & 19.7 & 17.6 & 15.9 & 15.6 & 17.4 & 19.1 & 20.2 & 21 & 21.4 & \\
\hline & & & 16.7 & 16.7 & 16.2 & 13.7 & 11.2 & 9 & 8.4 & 10 & 12.3 & 14.3 & 15.5 & 16.3 & $13.4 \pm 3.1$ \\
\hline & & Maximum & 26.8 & 27.2 & 27 & 25.8 & 24 & 22.9 & 22.9 & 24.9 & 25.9 & 26.2 & 26.6 & 26.6 & $25.6 \pm 1.5$ \\
\hline & & & 10.1 & 10.5 & 10.8 & 12.1 & 12.8 & 13.9 & 14.5 & 14.9 & 13.6 & 11.9 & 11.1 & 10.3 & $12.2 \pm 1.7$ \\
\hline & & & 280 & 227 & 185 & 74 & 47 & 37 & 24 & 29 & 71 & 120 & 183 & 254 & \\
\hline \multirow{5}{*}{$\begin{array}{l}\text { São Sebastião do } \\
\text { Paraíso } \\
\text { Latitude } 20^{\circ} 54^{\prime} \mathrm{S} \\
\text { Longitude } 47^{\circ} 6^{\prime} \mathrm{W} \\
\text { Altitude } 860 \mathrm{~m}\end{array}$} & \multirow{5}{*}{ Cwb } & Mean tem & 21.3 & 21.2 & 20.6 & 19.4 & 17.3 & 16.3 & 16.7 & 18.4 & 19.9 & 20.6 & 20.9 & 20.7 & $19.4 \pm 1.8$ \\
\hline & & Minimum temp & 17 & 16.8 & 15.9 & 14.1 & 11.5 & 10.1 & 10 & 11.7 & 13.7 & 15.4 & 16.3 & 15.9 & $14.0 \pm 2.6$ \\
\hline & & ture $\left({ }^{\circ} \mathrm{C}\right)$ & 25.6 & 25.7 & 25.4 & 24.7 & 23.2 & 22.6 & 23.5 & 25.2 & 26.1 & 25.8 & 25.5 & 25.5 & $24.9 \pm 1.2$ \\
\hline & & & 8.6 & 8.9 & 9.5 & 10.6 & 11.7 & 12.5 & 13.5 & 13.5 & 12.4 & 10.4 & 9.2 & 9.6 & $10.9 \pm 1.8$ \\
\hline & & Precipitation (mm) & 275 & 215 & 185 & 72 & 43 & 24 & 17 & 16 & 61 & 142 & 201 & 268 & 1519 \\
\hline
\end{tabular}

Table 2 - Soil classification and physicochemical properties of vineyards.

\begin{tabular}{|c|c|c|c|c|c|c|c|c|c|}
\hline \multirow{2}{*}{ Region } & \multirow{2}{*}{ Soil classification } & \multirow{2}{*}{ Soil Structure } & \multicolumn{3}{|c|}{ Fertility } & \multicolumn{3}{|c|}{ Texture } & \multirow{2}{*}{ Texture class } \\
\hline & & & $\mathrm{pH}$ & ${ }^{*}$ SBS & ${ }^{* *} \mathrm{SOM}$ & Clay & Silt & Sand & \\
\hline & & & \multicolumn{3}{|c|}{$\%$} & \multicolumn{3}{|c|}{ - dag kg $\mathrm{kg}^{-1}$} & \\
\hline TC & Acrudox 1 & Granular & 5.67 & 37.4 & 1.9 & 53 & 25 & 22 & Clay \\
\hline COR & Acrudox 2 & Granular & 6.03 & 50.9 & 2.1 & 58 & 18 & 24 & Clay \\
\hline TP & Hapludox & Granular & 5.87 & 53.4 & 1.5 & 48 & 38 & 14 & Clay \\
\hline SSP & Acrudox 3 & Granular & 6.57 & 46.4 & 1.6 & 37 & 28 & 35 & Clay Loam \\
\hline AND & Hapludult 1 & Blocks & 5.83 & 51.3 & 1.2 & 45 & 15 & 40 & Clay \\
\hline PIN & Hapludult 2 & Blocks & 5.18 & 40.1 & 1.2 & 46 & 11 & 43 & Clay \\
\hline ITO & Eutrudept & Blocks & 6.3 & 64.7 & 0.9 & 39 & 20 & 42 & Clay Loam \\
\hline
\end{tabular}

${ }^{*}$ SBS = soil base saturation; * *SOM = soil organic matter; TC = Três Corações; COR = Cordislândia; TP = Três Pontas; SSP = São Sebastião do Paraíso; AND = Andradas; PIN = Espírito Santo do Pinhal; ITO = Itobi.

and weighted using a digital balance, except for COR (2016 season) and TP (2016 and 2017 seasons) because the experimental sites had already been pruned by viticulturists when the data was collected.
Vine water status, stomatal conductance, and gas exchange measurements were performed only in 2017 and 2018, due to the availability of instruments. Water status corresponded to the water potential of the stem 
( $\Psi$ stem) and leaf ( $\Psi$ leaf) and was obtained using the pressure chamber method (Scholander et al., 1965). Ten replicates (one leaf per vine) were used to measure both variables. For $\Psi$ stem measurement, shaded leaves were sampled from the median portion of shoots (one leaf per plant) and were properly packed in plastic bags and aluminum foil to avoid transpiration for at least $1 \mathrm{~h}$ before measurements. For $\Psi$ leaf measurement, leaves exposed to the sun were collected from median portion of productive shoots of each plant and the reading was performed immediately.

Photosynthesis, transpiration, and stomatal conductance rates were measured from $10 \mathrm{~h} 00$ a.m. to $11 \mathrm{~h} 00 \mathrm{a} . \mathrm{m}$. in the same vines during the study years and along with water potential measurements, using a Li-6800 infrared gas analyzer. For this evaluation, ten adult leaves (1 per plant), healthy, completely exposed to sunlight and located in the median portion of productive shoots (with clusters) were selected.

\section{Yield components and fruit composition}

Grape ripeness was monitored in each site and for each winegrower to determine the optimum harvest date. At harvest, the number and weight of bunches were recorded on ten representative plants in all vines to estimate yield per vine and per hectare. Mean berry weight was estimated from a sample of 120 berries in ten replicates per vineyard. These berries were crushed in a polyethylene bag, filtered, and the resulting juice was immediately analyzed for total soluble solids (TSS; ${ }^{\circ}$ Brix) with a portable refractometer, and the $\mathrm{pH}$ of undiluted juice of each sample was determined using a Mettler $\mathrm{pH}$ meter, and titratable acidity (TA) was determined by titration of diluted juice with $0.1 \mathrm{~mol} \mathrm{~L}^{-1}$ of $\mathrm{NaOH}$ to a phenolphthalein end point at $\mathrm{pH} 8.2$ and expressed as $\mathrm{g} \mathrm{L}^{-1}$ tartaric acid (OIV, 2009).

Total anthocyanins and phenolic compounds were determined using ten replicates of 60 berries per treatment. The berry skin was removed, dried at room temperature, weighed, crushed with liquid nitrogen, and stored at $-80^{\circ} \mathrm{C}$ until the analyses. To determine the phenolic compounds, $0.2 \mathrm{~g}$ of the crushed skin were homogenized in Ultra Turrax in acidified methanol (1 \% HCL) solution. Anthocyanins were determined by the differential $\mathrm{pH}$ method /Giusti and Wrolstad, 2001). Total phenolics were analyzed by the Folin-Ciocalteau method based on a standard curve of gallic acid (Bergqvist et al., 2001).

\section{Statistical analysis}

The Principal Component Analysis (PCA) was performed on berries composition (Soluble solid, acidity, total anthocyanin and total phenolics) during the three harvests using the MetaboAnalyst Program (www. metaboanalyst.ca) to investigate the trends or group formations of berries from different regions. Then, agronomic and ecophysiological data were submitted to the analysis of variance (ANOVA) for each year using the
SISVAR (Computer Statistical Analysis System, version 5.6). The Scoot Knott test $(p<0.05)$ was carried out to compare the treatment means.

\section{Results}

\section{Macroclimate and vineyard soil description}

Vineyards under double-pruning management were located between 20 and $22^{\circ}$ of latitude south and between 45 and $47^{\circ}$ of longitude west at 840 to 1270 meters above sea level. All vineyards were located in a warm temperate zone with dry winter, defined as $\mathrm{Cw}$ type, according to the Köppen classification (Alvares et al., 2013). During the winter, precipitation is around $140 \mathrm{~mm}$ and during the summer, around $900 \mathrm{~mm}$ (Table 1). The viticultural zones were divided into two groups based on mean temperature during the hottest months of the year: Warm $>22^{\circ} \mathrm{C}$ at TC, TP, COR, AND and ITO; Mild $<22{ }^{\circ} \mathrm{C}$ at SSP and PIN. From May to July, when grape maturation occurs, the average minimum temperature in the Warm group is $9.2{ }^{\circ} \mathrm{C}( \pm 1.2)$ and average maximum is $24.4{ }^{\circ} \mathrm{C}( \pm 0.5)$, whereas in the Mild group is $10.1^{\circ} \mathrm{C}( \pm 1.2)$ and $23.1^{\circ} \mathrm{C}$ $( \pm 0.5)$, respectively. The highest thermal range $\left(15^{\circ} \mathrm{C} \pm\right.$ 0.12 ) occur at TC, COR and TP, followed by AND, PIN and ITO $\left(13.8^{\circ} \mathrm{C} \pm 0.10\right)$, whereas the lowest thermal range $\left(12.6^{\circ} \mathrm{C} \pm 0.9\right)$ occurs at SSP.

The study sites can be grouped into four soil types: Acrudox at TC, COR and SSP, Hapludox at TP, Hapludult at AND and PIN and, Eutrudept at ITO (Table 2). Acrudox and Hapludox soils are deep and mostly clayey with granular structure in the B-horizon, which promotes higher water permeability. Hapludult has increasing clay content increasing in depth and typical block structure in the B-horizon, which can decrease water infiltration. Eutrudept is shallow with the lowest water storage capacity among all four soil types. The Eutrudept soil at ITO had the lowest OM (1\%) content among all four soil types while Acrudox at COR had the highest OM content $(2 \%)$.

\section{Vegetative vigor and ecophysiological behavior of Syrah vines}

The estimated vine leaf area during the ripening period and the pruning weight measured after grape harvest differed between vineyards in all seasons (Table 3). Syrah leaf area ranged from 2.41 to $6.51 \mathrm{~m}^{2}$ per vine, depending on vineyard and growing season. In general, vines showed the highest leaf area at ITO, TC, and TP, whereas the lowest leaf area was observed in PIN, AND, and SSP in most years. In all growing seasons, PIN was always among the vineyards with the highest (around $0.5 \mathrm{~kg}$ per vine) pruning weight while at AND, SSP, and COR showed the lowest weight (around $0.34 \mathrm{~kg}$ per vine) values. In most growing seasons, the vineyard at ITO showed the highest leaf area and pruning weight while vineyards at SSP and AND had the lowest vegetative vigor. In contrast, Syrah vines at PIN showed low leaf area values and high pruning weight, probably favored 
by fertigation in this region during the beginning of shoot development.

Stem ( $\Psi$ stem) and leaf ( $\Psi$ leaf) water potentials varied between -0.42 and $-0.71 \mathrm{MPa}$ and -0.73 and -1.35 $\mathrm{MPa}$, respectively (Table 4). In both seasons, the vineyard at COR showed always higher $\Psi$ stem and $\Psi$ leaf, whereas vineyards at AND and ITO had lower water potentials. The rates of photosynthesis, stomatal conductance, and transpiration did not seem to be affected by vine water status, since some vineyards with the lowest values of $\Psi$ stem and $\Psi$ leaf showed the highest values of photosynthesis, transpiration, and stomatal conductance (Table 4).

\section{Yield and grape composition}

In all vineyards, yield increased during the years mainly, due to a larger number of clusters (Table 3). Depending on the vineyard and growing season, the number of bunches per vine ranged from seven to 26, weight ranged from 84 to $135 \mathrm{~g}$ per bunch, production ranged from 0.5 to $3.6 \mathrm{~kg}$ per vine, whereas yield ranged from two to $14 \mathrm{t} \mathrm{ha}^{-1}$. During the last two years (2017 and 2018), the highest production was observed at TP (11.08), TC (10.58), AND and COR (10.24), followed by PIN (9.04) and ITO (8.96), whereas vineyards at SSP showed the lowest yield in all growing seasons.
Grape composition differed between vineyards and seasons. Berries had a $\mathrm{pH}$ ranging from 3.16 to 3.87 , total soluble solids from 18.05 to $25.79{ }^{\circ}$ Brix and total acidity from 4.67 to $8.09 \mathrm{~g} \mathrm{~L}^{-1}$ tartaric acid (Table 5). The anthocyanin content ranged from 0.91 to $1.35 \mathrm{mg} g$ berry $^{-1}$, whereas total phenolics ranged from 2.77 to 4.22 mg g berries $^{-1}$ (Table 5).

Based on the Principal Component Analysis (PCA), the vineyards were grouped into three clusters. The first component explained $51 \%$ of the variation and showed ITO with negative scores, COR on the right side of the plot and AND, PIN, SSP, TC and TP joined together in the middle of the plot (Figure 2). The second component, sample variability and seasons, explained $31 \%$ of the variation. Vineyards at COR and ITO were more discriminated from other vineyards mainly due the largest differences observed in soluble solids and acidity. The grapes harvested at COR showed, on average, the lowest soluble solids (18.73 ${ }^{\circ}$ Brix) and the highest acidity $\left(7.19 \mathrm{~g} \mathrm{~L}^{-1}\right)$, whereas grapes at ITO showed the highest sugar content (23.51 ${ }^{\circ}$ Brix) and the lowest acidity $(4.91$ $\left.\mathrm{g} \mathrm{L}^{-1}\right)$. Despite some differences observed in phenolic compounds between vineyards and seasons (Table 5), the PCA could not separate the vineyards (Figure 1), suggesting that the harvest of berries during the winter had very similar phenolic profile.

Table 3 - Vegetative vigor (leaf area and pruning weight) and yield components of Syrah grapevines from different vineyards in Southeast Brazil during 2016, 2017, and 2018 autumn - winter growing seasons.

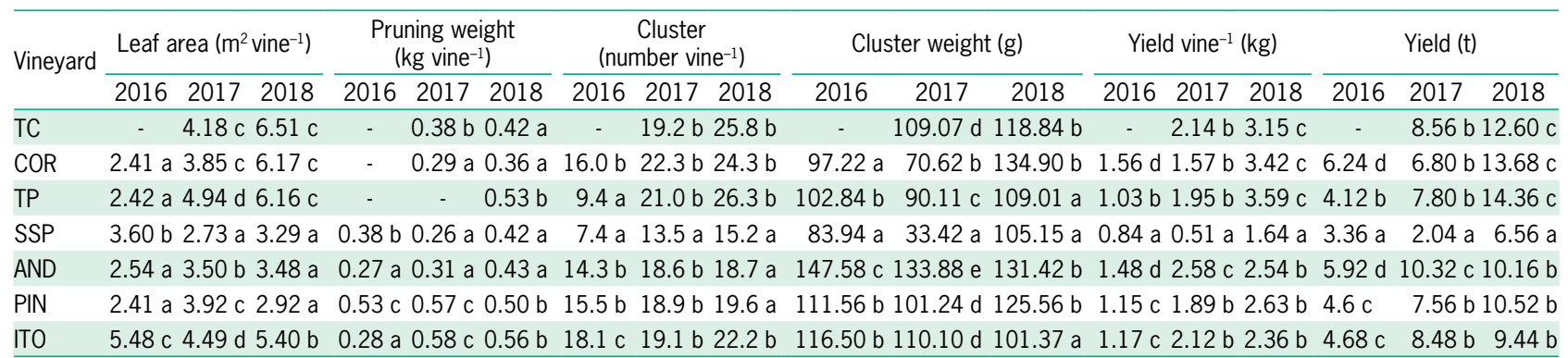

Values are means of ten replicates in three winter harvests (2016, 2017 and 2018 growing seasons). Means followed by the same letters in each season were not significantly different $(p<0.05)$ by the Scott Knott test. TC = Três Corações; COR = Cordislândia; TP = Três Pontas; SSP = São Sebastião do Paraíso; AND = Andradas; PIN = Espírito Santo do Pinhal; ITO = Itobi.

Table 4 - Vine water status (stem and leaf water potential - $\Psi$ stem and $\Psi$ leaf), photosynthesis, stomatal conductance, and transpiration of Syrah during the ripening stage in different vineyards of Southeast Brazil, during 2017 and 2018 winter growing seasons.

\begin{tabular}{|c|c|c|c|c|c|c|c|c|c|c|}
\hline \multirow{2}{*}{ Vineyard } & \multicolumn{2}{|c|}{$\Psi$ stem (MPa) } & \multicolumn{2}{|c|}{$\Psi$ leaf (MPa) } & \multicolumn{2}{|c|}{ Transpiration (mmol m-2 s-1) } & \multicolumn{2}{|c|}{ Photosynthesis ( $\mu \mathrm{mol} \mathrm{m} \mathrm{m}^{-2 \mathrm{~s}-1}$ ) } & \multicolumn{2}{|c|}{ Stomatal conductance $\left(\mathrm{mol} \mathrm{m}^{-2 \mathrm{~s}-1}\right)$} \\
\hline & 2017 & 2018 & 2017 & 2018 & 2017 & 2018 & 2017 & 2018 & 2017 & 2018 \\
\hline TC & $-0.51 c$ & $-0.53 c$ & $-0.88 c$ & $-0.99 d$ & $3.87 \mathrm{c}$ & $4.27 \mathrm{~b}$ & $8.88 b$ & $11.01 \mathrm{~b}$ & $0.157 b$ & $0.181 \mathrm{a}$ \\
\hline COR & $-0.42 d$ & $-0.48 d$ & $-0.73 d$ & -0.88 e & $4.22 \mathrm{c}$ & $6.01 \mathrm{c}$ & $9.20 \mathrm{~b}$ & $12.00 \mathrm{~b}$ & $0.178 c$ & $0.260 \mathrm{c}$ \\
\hline TP & $-0.49 c$ & $-0.57 b$ & $-1.03 b$ & $-1.04 c$ & $3.89 c$ & $5.36 \mathrm{c}$ & $8.52 b$ & $12.38 b$ & $0.153 b$ & $0.198 a$ \\
\hline SSP & $-0.47 c$ & $-0.51 c$ & $-0.78 d$ & $-0.97 d$ & $2.62 \mathrm{a}$ & $5.94 \mathrm{c}$ & $6.10 \mathrm{a}$ & $15.27 \mathrm{c}$ & 0.099 a & $0.245 b$ \\
\hline AND & $-0.66 a$ & $-0.48 d$ & $-1.24 a$ & $-1.27 b$ & $3.39 b$ & $6.19 c$ & $9.62 b$ & $11.95 b$ & $0.128 \mathrm{a}$ & $0.224 b$ \\
\hline PIN & $-0.50 c$ & $-0.59 b$ & $-0.92 c$ & $-1.05 c$ & $5.05 d$ & $2.90 \mathrm{a}$ & $10.95 \mathrm{c}$ & $9.13 \mathrm{a}$ & $0.208 c$ & $0.179 a$ \\
\hline ITO & $-0.61 b$ & $-0.71 \mathrm{a}$ & $-1.09 b$ & $-1.35 a$ & $4.62 \mathrm{~d}$ & $6.28 c$ & $10.95 \mathrm{c}$ & $16.59 \mathrm{~d}$ & $0.205 c$ & $0.278 c$ \\
\hline
\end{tabular}

Means followed by the same letters in each season were not significantly different $(p<0.05)$ by the Scott Knott test. TC $=$ Três Coracões; COR $=$ Cordislândia; TP $=$ Três Pontas; SSP = São Sebastião do Paraíso; AND = Andradas; PIN = Espírito Santo do Pinhal; ITO = Itobi. 
Table 5 - Grape composition at harvest in seven vineyards in Southeast Brazil.

\begin{tabular}{|c|c|c|c|c|c|c|c|c|c|c|c|c|c|c|c|c|c|c|}
\hline \multirow[t]{2}{*}{ Vineyard } & \multicolumn{3}{|c|}{ Berry Weight (g) } & \multicolumn{3}{|c|}{$\mathrm{pH}$} & \multicolumn{3}{|c|}{ TSS ( ${ }^{\circ}$ Brix) } & \multicolumn{3}{|c|}{ Acidity $\left(\mathrm{g} \mathrm{L}^{-1}\right)$} & \multicolumn{3}{|c|}{$\begin{array}{l}\text { Total Anthocyanins } \\
\left(\mathrm{mg} \mathrm{g} \text { berry }{ }^{-1}\right)\end{array}$} & \multicolumn{3}{|c|}{$\begin{array}{l}\text { Total Phenolics } \\
\text { (mg g berry }{ }^{-1} \text { ) }\end{array}$} \\
\hline & 2016 & 2017 & 2018 & 016 & 2017 & 2018 & 2016 & 2017 & 2018 & & 2017 & 2018 & 2016 & 2017 & 2018 & 2016 & 2017 & 2018 \\
\hline & - & & $1.25 \mathrm{a}$ & - & $3.45 b$ & 3.49 & & & & & & & - & $1.30 \mathrm{~b}$ & & - & $3.06 \mathrm{a}$ & \\
\hline OR & $25 \mathrm{~b}$ & & $1.35 \mathrm{~b}$ & $16 \mathrm{a}$ & $3.3 \mathrm{a}$ & $3.46 \mathrm{a}$ & & & & & & & $1.22 \mathrm{~d}$ & & & $4.22 \mathrm{~d}$ & & \\
\hline$P$ & & & & $9 d$ & $3.7 \mathrm{~d}$ & $3.72 \mathrm{c}$ & & & & & & & $4 c$ & & & $3.79 c$ & & $36 a$ \\
\hline SP & 36 & & $1.25 \mathrm{a}$ & $66 \mathrm{e}$ & $3.58 c$ & $3.69 c$ & 20.81 & & & & & & 1.2 & & & 3.53 & & \\
\hline VD & & & & 34 & & $3.49 a$ & & & & & & & $1.35 \mathrm{e}$ & & & $3.37 \mathrm{~b}$ & & $2.77 \mathrm{a}$ \\
\hline & $1.32 \mathrm{c}$ & $1.14 \mathrm{~b}$ & $1.23 \mathrm{a}$ & $49 \mathrm{~b}$ & $3.46 b$ & $3.58 b$ & $21.21 \mathrm{~d}$ & $22.49 \mathrm{c}$ & $22.86 \mathrm{c}$ & $44 \mathrm{e}$ & $6.07 c$ & $5.50 \mathrm{~b}$ & $0.91 \mathrm{a}$ & 102 & $0.98 a$ & $2.98 \mathrm{a}$ & 3.14 & $3.08 a$ \\
\hline TO & $1.29 c$ & $1.14 \mathrm{~b}$ & $1.20 \mathrm{a}$ & $3.7 \mathrm{f}$ & $3.75 \mathrm{~d}$ & $3.87 \mathrm{~d}$ & $21.99 \mathrm{e}$ & $22.74 \mathrm{c}$ & $25.79 \mathrm{~d}$ & $5.31 \mathrm{a}$ & $4.67 \mathrm{a}$ & $4.74 \mathrm{a}$ & $1.08 \mathrm{~b}$ & $1.18 b$ & $0.98 a$ & $3.53 b$ & $3.49 a$ & $3.02 a$ \\
\hline
\end{tabular}

Means followed by the same letters in each season were not significantly different $(p<0.05)$ by the Scott Knott test. TC $=$ Três Coraccões; COR $=$ Cordislândia; TP $=$ Três Pontas; SSP = São Sebastião do Paraíso; AND = Andradas; PIN = Espírito Santo do Pinhal; ITO = Itobi. TSS = Total soluble solids.
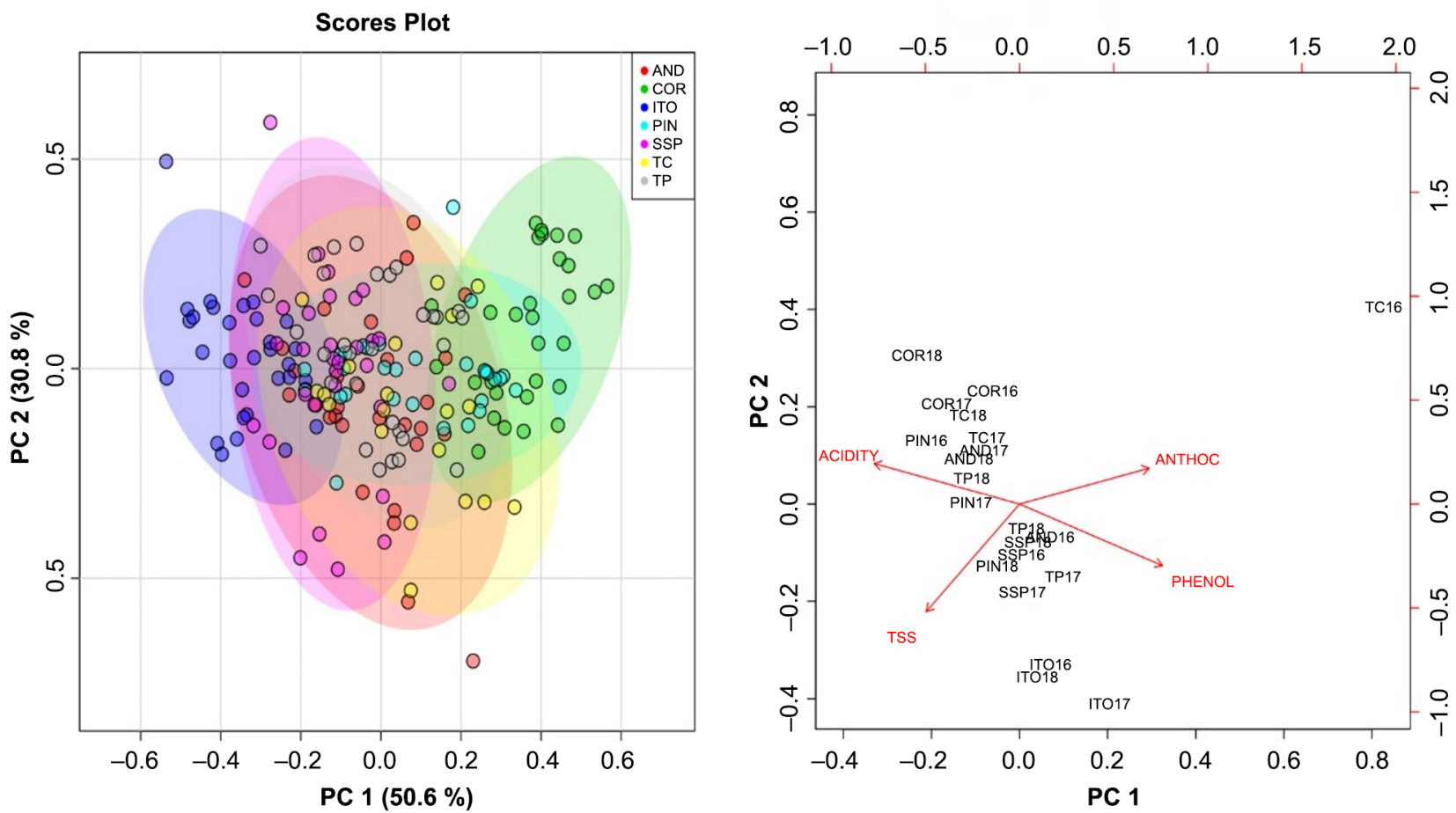

Figure 2 - Principal Component Analysis (PCA) of grape composition (soluble solids, acidity, total anthocyanin, and total phenolics) from seven vineyards in southeastern Brazil in 2016, 2017, and 2018 winter seasons. Andradas (AND), Cordislândia (COR), Itobi (ITO), Pinhal (PIN), São Sebastião do Paraíso (SSP), Três Corações (TC), and Três Pontas (TP).

\section{Discussion}

In this study, the vineyards under doublepruning management from different municipalities were characterized based on soil type, vegetative vigor, yield, and grape quality. The high variability in vine vigor and grape yield between vineyards seemed to be more related to vineyard management rather than soil and climate effects, mainly because vineyards under similar soil types showed differences in vigor components during the seasons (Tables 2 and 3). There was no relationship between vigor and soil type for most vineyards. Differences in canopy management from each viticulturist probably contributed to the wide variability in vigor among vineyards. Furthermore, differences in grape composition were not attributed to variation on vegetative vigor and productivity.

In general, Syrah vines at all sites ripened to full maturity. The levels of sugar, titratable acidity, anthocyanin, and total phenolic compounds (Table 5) of winter harvest remained within the range suitable to produce high quality wine (Ojeda et al., 2002; PenãNeira et al., 2007) and within ranges usually observed for Syrah grapes from the main wine growing regions in the world (Keller et al., 2012; Ristic et al., 2007). This may help explain why winter wines from different 
geographical origins of southeastern Brazil have been awarded nationally and internationally. The high thermal amplitude and low rainfall during autumn-winter observed in all municipalities seemed to be the main factor for improvement of phenolic compounds and soluble solids, also reported in previous studies (Favero et al., 2011; Mota et al., 2010).

The main limiting factor for the adoption of doublepruning management in some locations of Southeast Brazil has been the low autumn-winter temperature during the grape-ripening stage. Mota et al. (2010) report that at the high altitudes $(1,150 \mathrm{~m})$ observed in the municipality of Caldas, southern Minas Gerais, grape and wine quality could be impaired by winter freezing temperature. In our study, most vineyards were located at elevation below 900 $\mathrm{m}$, except for PIN $(1,270 \mathrm{~m})$ and AND $(1,000 \mathrm{~m})$ (Table 1). According to historical regional climate data, however, vineyards at high altitudes are within climatic zones with the same thermal regimes, during the ripening period, as observed in zones of vineyards at low altitudes (Table 1).

Although rainfall is reduced from May to Aug (Table 1), the high clay content ( $>35 \%$ ) observed in all soils, associated to the low evapotranspiration demand, due to air temperature reduction, prevented the occurrence of severe water deficit in vines during the maturation stage. The values of stem and leaf water potentials showed that Syrah vines had a moderate-to-weak water stress only at AND and ITO when compared to the reference values (Van Leeuwen et al., 2009) (Table 4). Although these physiological variables are also highly dependent on atmospheric conditions, specifically vapor pressure deficit, temperature, and solar radiation, the high sand content in soils at ITO and AND possibly had lower water holding capacity therefore affecting the vine water status, compared to the other vineyards (Table 2). Conversely, photosynthesis, transpiration, and stomatal conductance were not negatively affected. In all vineyards, results on photosynthesis, transpiration, and stomatal conductance are within the range usually observed in well-watered vineyards (Prieto et al., 2010; Souza et al., 2003).

The PCA including all components of must composition separated only ITO and COR from the other vineyards, based only on the acidity and soluble solids contents. However, the effect of soil type and macroclimate might explain the highest sugar concentration and low acidity in berries only at ITO. Although the block structure and clay loam texture of Eutrudept soil of ITO possibly led to smaller berries, favoring sugar accumulation, there was no significant reduction of bunch and berry weight (Tables 3 and 5). On the other hand, moderate water stress indicated by values of stem and leaf water potential of Syrah vines at ITO possibly enhanced grape ripening, as observed in some studies (Acevedo-Opazo et al., 2010; Deloire et al., 2004). Moreover, the highest photosynthetic rates also seemed to increase soluble solids (Table 4), since photosynthesis is the main source of sugar accumulation in berries (Conde et al., 2007). The highest photosynthetic rates observed in ITO vineyards were also possibly favored by the higher minimum and maximum temperature historically recorded at ITO, compared to the other municipalities (Table 1). The lowest berry acidity at ITO was also more related to high air temperature than to soil type, since malic acid degradation is stimulated by high diurnal temperature (Oliveira et al., 2019; Tonietto and Carbonneau, 2004). The lowest total acidity of Syrah winter wines at ITO (4.92 $\left.\mathrm{g} \mathrm{L}^{-1}\right)$, compared to PIN (5.78 $\left.\mathrm{g} \mathrm{L}^{-1}\right)$, TC (5.30 $\left.\mathrm{g} \mathrm{L}^{-1}\right)$ and Caldas $\left(6.20 \mathrm{~g} \mathrm{~L}^{-1}\right)$, has been attributed to higher diurnal berry temperature observed at ITO $\left(24^{\circ} \mathrm{C}\right)$, compared to PIN $\left(21.48{ }^{\circ} \mathrm{C}\right)$, TC (20.78 $\left.{ }^{\circ} \mathrm{C}\right)$, and Caldas $\left(19.18{ }^{\circ} \mathrm{C}\right)$. Van Leeuwen et al. (2004) also observed that total grape juice acidity depends on the harvest and on the soil type, to a lesser extent.

Although the PCA highlighted COR with the lowest soluble solids and highest acidity in berries, final ripeness at COR was penalized mainly by early harvesting decision of the viticulturist. Grapes should be harvested later in the season, since the soil at COR has high clay and $\mathrm{OM}$ contents and consequent greater water retention. However, as mentioned in the methodology, the harvest time was established by the owner of the commercial vineyards.

Were found significant differences to anthocyanins and total phenols of berries between vineyards (Table 5). However, according to the PCA, phenolic compounds (Figure 2) could not separate the vineyards. These results suggest that phenolic ripeness during autumn-winter season was less sensitive to soil characteristics and air temperature than sugar and acidity. As mentioned previously, the high thermal amplitude and low rainfall during ripening of the winter cycle were the main factors to increase synthesis and accumulation of anthocyanins and total phenols in wine grapes, compared to summer cycles in Southeast Brazil (Favero et al., 2011; Mota et al., 2010). The slight differences in levels of phenolic compounds between viticultural zones could be due to a small variation in altitudes of vineyards and, therefore, small differences on thermal amplitude, the main climatic factor for the synthesis of phenolic compounds (Mori et al., 2005; Spayd et al., 2002).

In all vineyards, regardless of yield, Syrah vines fully ripened the grapes. The high yield ( $3 \mathrm{~kg}$ per vine) on clayey soils also showed high leaf area $\left(>6 \mathrm{~m}^{2}\right.$ per vine). Vines under single-canopy trellis systems are considered well balanced and capable to producing high-quality grapes when the ratio of leaf area/yield ranges from 0.8 to $1.2 \mathrm{~m}^{2} \mathrm{~kg}^{-1}$ (Kliewer and Dokoozlian, 2005) or the ratio of yield/pruning weight ranges from 5 to 10 (Smart et al., 1990). Thus, most vineyards could be considered unbalanced, since several vines showed higher values of leaf area/yield $\left(>1.4 \mathrm{~m}^{2} \mathrm{~kg}^{-1}\right)$ and lower yield/pruning weight $(>2)$. However, temperature and light for maximum photosynthesis are frequently more limited under cold conditions of the winter season. Therefore, grapevines growing under low temperature of autumn-winter conditions of Southeast Brazil require mainly higher leaf area/fruit weight ratio to ripen their 
crops. Dias et al. (2017) also showed that grape and wine composition of Syrah vines, grown during the winter cycle in southern Minas Gerais, was not impaired by the ratio higher than $2 \mathrm{~m}^{2}$ of leaf area per $\mathrm{kg}$ of fruit.

\section{Conclusion}

The macro-scale evaluation of seven viticultural zones in Southeast Brazil, managed with double-pruning technique to change the harvest from wet summer to dry winter, showed similar grape compositions, despite soil or climate differences. Although characterized with four different soil types, all vineyards have high clay content, which allowed enough water supply during the dry winter season.

Variability of vine vigor and grape production was more correlated to vineyard management than to soil or weather conditions.

The content of soluble sugars and acidity of berries were the factors that most distinguished the vineyards. The soil type and higher temperature in Itobi resulted in higher soluble solids contents and lower acidity of berries, while in Cordislândia, the earlier harvest influenced these results in the opposite way. Anthocyanin and phenolic levels did not discriminate any vineyard, despite differences in soil and climate conditions.

The human factor, mainly harvest decision, is fundamental to have high quality berries to obtain the best expression of terroir in the autumn-winter viticulture in southeastern Brazil with the doublepruning technique. The natural characteristics of terroir, such as climate, soil, and agronomic expression of the grapevine, evidenced the potential of the region for high-quality wine production.

\section{Acknowledgements}

This study was financially supported by the National Council for Scientific and Technological Development (CNPq), Minas Gerais State Foundation for Research Support (FAPEMIG), Coordination for higher Education Staff Development (CAPES) and by wineries Estrada Real, Maria Maria, Casa Verrone, Stella Valentino, Luiz Porto, Guaspari and Agricultural Research Company of Minas Gerais (EPAMIG). The authors are also grateful to I. Magalhães for the berry chemical analyses and to D. Rodrigues for the technical support in the vineyards.

\section{Authors' Contributions}

Conceptualization: Brant, L.A.C.; Curi, N.; Mota, R.V.; Regina, M.A.; Souza, C.R. Data acquisition: Brant, L.A.C.; Fernandes, F.P.; Gonçalves, M.G.M.; Menezes, M.D.; Mota, R.V.; Peregrino, I.; Souza, C.R. Data analysis: Brant, L.A.C.; Gonçalves, M.G.M.; Mota, R.V.; Souza, C.R. Design of methodology: Brant, L.A.C.; Mota, R.V.; Regina, M.A.; Souza, C.R. Writing and editing: Brant, L.A.C.; Curi, N.; Fernandes, F.P; Gonçalves, M.G.M.; Menezes, M.D.; Mota, R.V.; Peregrino, I.; Regina, M.A.; Souza, C.R.

\section{References}

Acevedo-Opazo, C.; Ortega-Farias, S.; Fuentes, S. 2010. Effects of grapevine (Vitis vinifera L.) water status on water consumption, vegetative growth and grape quality: an irrigation scheduling application to achieve regulated deficit irrigation. Agricultural Water Management 97: 956-964.

Alvares, C.A.; Stape, J.L.; Sentelhas, P.C.; Gonçalves, J.L.M.; Sparovek, G. 2013. Köppen's climate classification map for Brazil. Meteorologische Zeitschrift 22: 711-728.

Ballantyne, D.; Terblanche, N.S.; Lecat, B.; Chpuis, C. 2019. Old world and new world wine concepts of terroir and wine: perspectives of three renowned non-French wine makers. Journal of Wine Research 30: 122-143.

Bergqvist, J.; Dokoozlian, N.; Ebisuda, N. 2001. Sunlight exposure and temperature effects on berry growth and composition of Cabernet Sauvignon and Grenache in the central San Joaquin Valley of California. American Journal of Enology and Viticulture 52: 1-7.

Brant, L.A.C.; Figueredo, G.M.; Mota, R.V. 2018. Winter wines from southeast Brazil = Vinhos de inverno do sudeste brasileiro. 2018. Territoires du vin 9. Available in: https://preo.ubourgogne.fr/territoiresduvin/index.php?id = 1615\&lang =en [Accessed Feb 27, 2020] (in Portuguese).

Coggins, S.; Malone, B.P.; Stockmann, U.; Possell, M.; McBratney, A.B. 2019. Towards meaningful geographical indications: validating terroirs on a $200 \mathrm{~km}^{2}$ scale in Australia's lower Hunter Valley. Geoderma Regional 16.

Conde, C.; Silva, P.; Fontes, N.; Dias, A. C. P.; Tavares, R. M.; Sousa, M. J.; Agasse, A.; Delrot, S.; Gerós, H. 2007. Biochemical changes throughout grape berry development and fruit and wine quality. Global Science Books 1: 1-22.

Deloire, A.; Carbonneau, A.; Wang, Z.; Ojeda, H. 2004. Vine and water: a short review. Journal International des Sciences de la Vigne et du Vin 38: 1-13.

Dias, F.A.N.; Mota, R.V.; Souza, C.R.; Pimentel, R.M.A.; Souza, L.C.; Souza, A.L.; Regina, M.A. 2017. Rootstock on vine performance and wine quality of 'Syrah' under double pruning. Scientia Agricola 74: 134-141.

Favero, A.C.; Amorim, D.A.; Mota, R.V.; Soares, A.M.; Souza, C.R.; Regina, M.A. 2011. Double-pruning of 'Syrah' grapevines: a management strategy to harvest wine grapes during the winter in the Brazilian Southeast. Vitis 50: 151-158.

Gee, G.W.; Bauder, J.W. 1986. Methods of Soil Analysis. Part 1. Physical and Mineralogical Methods. Soil Science Society of America, Madison, WI, USA.

Giusti, M.M.; Wrolstad, R.E. 2001. Characterization and Measurement of Anthocyanins by UV-Visible Spectroscopy: Current Protocols in Food Analytical Chemistry. John Willey, New York, NY, USA.

Keller, M.; Mills, L.J.; Harbertson, J.F. 2012. Rootstock effects on deficit-irrigated winegrapes in a dry climate: vigor, yield formation, and fruit ripening. American Journal of Enology and Viticulture 63: 1. 
Kliewer, W.M.; Dokoozlian, N.K. 2005. Leaf area/crop weight ratios of grapevines: influence on fruit composition and wine quality. American Journal of Enology and Viticulture 56: 170181.

Mota, R.V.; Favero, A.C.; Silva, C.P.C.; Purgatto, E.; Shiga, T.M.; Regina, M.A. 2011a. Wine grape quality of grapevines grown in the cerrado ecoregion of Brazil. Journal International des Sciences de la Vigne et du Vin 45: 101-109.

Mota, R.V.; Amorim, D.A.; Favero, A.C.; Purgatto, E.; Regina, M.A. 2011b. Effect of trellising system on grape and wine composition of Syrah vines grown in the Cerrado region of Minas Gerais. Ciência e Tecnologia de Alimentos 31: 967-972.

Mota, R.V.; Silva, C.P.C.; Favero, A.C.; Purgatto, E.; Shiga, T.M.; Regina, M.A. 2010. Physico-chemical composition of wine grapes berries in summer and winter growing seasons. Revista Brasileira de Fruticultura 32: 1127-1137.

Mori, K.; Saito, H.; Got-Yamamoto, N.; Kitayama, M.; Kobayashi, S.; Sugay, S.; Gemma; H.; Hashizume, K. 2005. Effects of abscisic acid treatment and night temperature on anthocyanin composition in Pinot noir grapes. Vitis. Siebeldingen 44:161165

Oliveira, J.B.; Egipto, R.; Laureano, O.; Castro, R.; Pereira, G.E.; Silva. J.M.R. 2019. Climate effects on physicochemical composition of Syrah grapes at low and high altitude sites from tropical grown regions of Brazil. Food Research International 121: 870-879.

Ojeda, H.; Andary, C.; Kraeva, E.; Carbonneau, A.; Deloire, A. 2002. Influence of pre and postveraison water deficit on sintesis and concentration of skin phenolic compounds during berry growth of vitis vinifera L., cv. Shiraz. American Journal Enology and Viticulture 53: 261-267.

Organization Internationale de la Vigne et du Vin. [OIV]. 2009. Compendium of International Methods of Wine and Must Analysis. OIV, Paris, France.

Penã-Neira, A.; Cáceres, A.; Pastenes, C. 2007. Low Molecular Weight Phenolic and Anthocyanin Composition of Grape Skins from cv. Syrah (Vitis vinifera L.) in the Maipo Valley (Chile): effect of clusters thinning and vineyard yield. Food Science and Technology International 13: 153-158.

Prieto, J.A.; Lebon, E.; Ojeda, H. 2010. Stomatal behavior of different grapevine cultivars in response to soil water status and air water vapor pressure deficit. Journal International des Sciences de la Vigne et du Vin 44: 9-20.

Regina, M.A.; Mota, R.V.; Souza, C.R.; Favero, A.C. 2011. Viticulture for fine wines in Brazilian southeast. Acta Horticulturae 910: 113-120.

Regina, M.A.; Pereira, G.E.; Cançado, G.M.A.; Rodrigues, D.J. 2000. Calculate of the leaf area on grapevine through nondestructive method. Revista Brasileira de Fruticultura 22: 310- 313 .
Ristic, R.; Downey, M.O.; Iland, P.G.; Bindon, K.; Francis, I.L.; Herderick, M.; Robinson, S.P. 2007. Exclusion of sunlight from Shiraz grapes alters wine colour, tannin and sensory properties. Australian Journal of Grape and Wine Research 13: 53-65.

Santos, R.D.; Santos, H.G.; Ker, J.C.; Anjos, L.H.C.; Shimizu, S.H. 2015. Field Description and Soil Collect Manual = Manual de Descrição e Coleta de Solo no Campo. 7ed. Sociedade Brasileira de Ciência do Solo. Viçosa, MG, Brazil (in Portuguese).

Scholander, P.F.; Hammel, H.T.; Hemingsen, E.A.; Bradstreet, E.D. 1965. Hydrostatic pressure and osmotic potencials in leaves of mangroves and some other plants. Proceedings of the National Academy of Science 51: 119-125.

Smart, R.E.; Dick, J.K.; Gravett, I.M.; Fisher, B.M. 1990. Canopy management to improve grape yield and wine quality: principles and practices. South African Journal for Enology and Viticulture 11: 3-17.

Soil Survey Staff. 2014. Keys to Soil Taxonomy. 12ed. USDANatural Resources Conservation Service, Washington, DC, USA.

Souza, C.S.; Maroco, J.P.; Santos, T.P.; Rodrigues, M.L.; Lopes, C.M.; Pereira, J.S.; Chaves, M.M. 2003. Partial rootzone drying: regulation of stomatal aperture and carbon assimilation in field-grown grapevines (Vitis vinifera cv. Moscatel). Functional Plant Biology 30: 653-662.

Spayd, S.E.; Tarara, J.M.; Mee. D.L.; Fergusun, J.C. 2002. Separation of sunlight and temperature effects on the composition of Vitis vinífera cv. Merlot berries. American Journal of Enology and Viticulture 53: 171-181.

Tonietto, J.; Carbonneau, A. 2004. A multicriteria climatic classification system for grape growing regions worldwide. Agricultural and Forest Meteorology 124: 81-97.

Van Leeuwen, C.V. 2010. Terroir: The effect of the physical environment on the vine growth, grape ripening and wine sensory attributes. Woodhead Publishing, Bordeaux 1: 273315.

Van Leeuwen, C.V.; Friant, P.; Choné, X.; Tregoat, O.; Koundouras, S.; Dubourdieu, D. 2004. Influence of climate, soil, and cultivar on terroir. American Journal of Viticulture and Enology 55: 207-217.

Van Leeuwen, C.V; Tregoat, O.; Choné, X.; Bois, B.; Pernet, D.; Gaudièllere, J.P. 2009. Vine water status is a key factor in grape ripening and vintage quality for red Bordeaux wine: how can it be assessed for vineyard management purposes. Journal International des Sciences de la Vigne et du Vin 43: 121-134. 